Situs Jurnal : http://ejurnal.stiepancasetia.ac.id/index.php/jieb

Jilid 4 Nomor 3 November 2018

Hal 377 - 390

\title{
PENGARUH DISTRIBUSI, LAYANAN PURNA JUAL, CITRA MEREK DAN FANATISME MEREK TERHADAP LOYALITAS PELANGGAN DENGAN KEPUASAN PELANGGAN SEBAGAI VARIABEL INTERVENING PADA KONSUMEN MOBIL MEREK TOYOTA DI BANJARMASIN
}

\begin{abstract}
Abul Hasan Asy'ari*
Abstract: This study aims to determine the effect of distribution variables, after sales service, brand image and brand fanaticism on customer loyalty of Toyota brand cars with customer satisfaction as an intervening variable. This research is a correlational research with the population is all people who own and use Toyota cars that qualify the requirements of the respondents. The sample in this study were 100 respondents. The results show that (1). Simultaneous distribution variables, after sales service, brand image and brand fanaticism have a significant effect on customer satisfaction and customer loyalty. (2). Partially the Distribution and Brand Image variables have no significant effect on Customer Loyalty, While After Sales Service, Brand Fanaticism and Customer Satisfaction variables have a significant influence on Customer Loyalty
\end{abstract}

Keywords: distribution, after sales service, brand image, brand fanaticism, customer loyalty

Abstrak: Penelitian ini bertujuan untuk mengetahui pengaruh variabel Distribusi, Layanan Purna Jual, Citra Merek dan Fanatisme Merek terhadap Loyalitas Pelanggan mobil merek Toyota dengan Kepuasan Pelanggan sebagai variabel Intervening. Penelitian ini merupakan penelitian korelasional dengan populasi adalah seluruh masyarakat yang memiliki dan menggunakan mobil Toyota yang memenuhi syarat sebabagai responden. Sampel dalam penelitian ini adalah 100 responden. Hasil penelitian menunjukkan bahwa (1). Seacara simultan variabel Distribusi, Layanan Purna Jual, Citra Merek dan Fanatisme Merek berpengaruh signifikan terhadap Kepuasan Pelanggan dan Loyalitas Pelanggan. (2). Secara parsial variabel Distribusi dan Citra Merek tidak berpengaruh signifikan terhadap Loyalitas Pelanggan, Sedangkan variabel Layanan Purna Jual, Fanatisme Merek dan Kepuasan Pelanggan berpengaruh signifikan terhadap Loyalitas Pelanggan

Kata kunci : distribusi, layanan purna jual, citra merek, fanatisme merek, loyalitas pelanggan

\section{Latar Belakang}

Dewasa ini persaingan dunia usaha semakin bertambah ketat, tidak terkecuali industri otomotif khususnya industri mobil di Indonesia. Industri ini memberikan kontribusi yang cukup besar dalam menopang pertumbuhan ekonomi nasional, mengingat industri mobil merupakan industri dengan value yang tinggi maka bagi perusahaan yang mampu bersaing dan merebut pangsa pasar akan mendapatkan keuntungan yang besar, namun di balik itu industri ini menyuguhkan persaingan yang sangat kompetitif.

Setiap ajang expo seperti GIIAS pabrikan raksasa motor seperti Toyota, Honda, Suzuki, Mitsubhisi, Cevrolet, Ford dan lain-lain saling berlomba-lomba dalam menciptakan 
varian dan model terbaru andalan mereka dengan tujuan menarik minat beli masyarakat. Dalam meningkatkan daya saing, suatu perusahaan dapat memenangkan persaingan dengan cara menampilkan produk terbaik yang dapat memenuhi selera konsumen. Pada dasarnya semakin tinggi tingkat persaingan maka semakin banyak pilihan bagi konsumen untuk memilih produk yang sesuai dengan keinginan dan harapan konsumen.

Toyota merupakan merek mobil yang sangat terkenal di pasar global dan merupakan fabrikan mobil terbesar di dunia. Tidak terkecuali di Indonesia Toyota menjadi pioneer dalam industri otomotif (mobil) dan merupakan mobil yang sangat familiar, serta menjadi mobil yang paling digemari masyarakat Indonesia.

Mobil toyota dari tahun ke tahun selalu menjadi market leader atau pemimpin pasar di Indonesia, sebagai bukti kepemimpinan Toyota, Seperti di tahun-tahun sebelumnya, Toyota pada 2016 ini masih menjadi pemimpin atau market leader di pasar otomotif nasional. Hingga Agustus 2016, penjualan keseluruhan (wholesales) Toyota sudah mencapai 238.795 unit dengan market share 34,56 persen. Posisinya masih dibuntuti Honda yang telah menjual 136.058 unit dan Daihatsu 116.999 unit. Tradisi sebagai pemimpin pasar selalu terus menerus di jaga oleh Toyota.

PT. Toyota Astra Motor (TAM) sebagai agen tunggal pemegang merek di Indonesia dan telah memainkan peranan penting dalam pengembangan industri otomotif di Indonesia. Selama 45 tahun, hampir 5 juta unit kendaraan yang telah berhasil dipasarkan Toyota Indonesia di pasar dalam negeri. Bersamaan dengan itu, pada bulan September, 1 juta unit model Toyota buatan Indonesia berhasil di ekspor ke mancanegara dalam bentuk kendaraan utuh.

Berdasarkan pada latar belakang diatas maka dapat disusun serangkaian rumusan masalah sebagai berikut :

1. Apakah Variabel Distribusi, Layanan Purna Jual, Citra Merek, dan Fanatisme Merek berpengaruh signifikan secara simultan terhadap Kepuasan Pelanggan.

2. Apakah Variabel Distribusi, Layanan Purna Jual, Citra Merek, dan Fanatisme Merek berpengaruh signifikan secara simultan terhadap Loyalitas Pelanggan.

3. Apakah Variabel Distribusi, berpengaruh signifikan terhadap Kepuasan Pelanggan

4. Apakah Variabel Layanan Purna Jual berpengaruh signifikan terhadap Kepuasan Pelanggan.

5. Apakah Variabel Citra Merek, berpengaruh signifikan terhadap Kepuasan Pelanggan.

6. Apakah Variabel Fanatisme Merek, berpengaruh signifikan terhadap Kepuasan Pelanggan.

7. Apakah Variabel Distribusi, berpengaruh signifikan terhadap Loyalitas Pelanggan

8. Apakah Variabel Layanan Purna Jual, berpengaruh signifikan terhadap Loyalitas Pelanggan

9. Apakah Variabel Citra Merek, berpengaruh signifikan terhadap Loyalitas Pelanggan

10. Apakah Variabel Fanatisme Merek, berpengaruh signifikan terhadap Loyalitas Pelanggan

11. Apakah Variabel Kepusan Pelanggan, berpengaruh signifikan terhadap Loyalitas Pelanggan

\section{Kajian Literatur}

Menurut Kotler dan Amstrong (2001) bahwa industri termasuk aktifitas perusahaan untuk membuat produk tersedia bagi konsumen sasaran. Saluran distribusi adalah sekelompok pedagang dan agen perusahaan yang mengkombinasikan antara pemindahan fisik dan nama dari suatu produk untuk menciptakan kegunaan bagi pasar tertentu. Dari definisi diatas, dapat disimpulkan bahwa distribusi adalah kegiatan-kegiatan pengiriman barang yang dilakukan 
oleh suatu organisasi dengan tujuan agar produk yang dihasilkannya dapat diterima oleh konsumen baik melalui perantara ataupun tidak.

Menurut Kotler(2007), Saluran Distribusi adalah suatu perangkat organisasi yang tergantung yang tercakup dalam proses yang membuat produk atau jasa menjadi untuk digunakan atau dikonsumsi oleh konsumen atau pengguna bisnis.Menurut Keegan (2003), Saluran Distribusi adalah saluran yang digunakan oleh produsen untuk menyalurkan barang tersebut dari produsen sampai ke konsumen atau pemakai industri.

Layanan purna jual adalah suatu layanan yang disediakan oleh produsen kepada konsumen setelah konsumen tersebut membeli produk dari perusahaan tersebut Tjiptono (2008). Sedangkan menurut Kotler dan Armstrong (2008) Layanan purna jual adalah suatu layanan yang disediakan oleh produsen kepada konsumen setelah konsumen tersebut membeli produk dari perusahaan tersebut. Menurut Kotler dan Keller (2008) layanan purna jual adalah untuk memberikan dukungan terbaik, perusahaan memberikan layanan purna jual, sebagian besar perusahaan bergerak melalui beberapa tahap.

Berdasarkan pengertian di atas dapat disimpulkan bahwa layanan purna jual adalah suatu kegiatan yang dilaksanakan setelah penyerahan produk kepada konsumen atas pembeliannya, yang berlaku selama konsumen ada ikatan layanan atau hubungan dalam berbagai kegiatan layanan.

Layanan purna jual memiliki beberapa unsur, sebagaimana dikemukakan oleh Kotler dan Armstrong (2008) bahwa unsur-unsur dalam layanan purna jual adalah sebagai berikut:

1. Garansi

Garansi merupakan salah satu faktor yang sangat penting dalam melaksanakan layanan purna jual, garansi ditunjukan untuk meyakinkan konsumen bahwa produk dalam keadaan baik atau bebas dari kerusakan, akibat dari ketidaktelitian pengarjaan atau penggunaan material yang kurang baik yang berlaku untuk jangka waktu tertentu.

2. Penyediaan Aksesoris

Dalam pelaksanaan layanan purna jual, penyediaan suku cadang merupakan hal yang sangat penting, sebab tanpa adanya suku cadang produk yang sudah rusak komponennya tidak dapat berfungsi dengan baik, bahkan produk tersebut tidak dapat dipakai lagi. Mengatakan penyediaan accessories merupakan salah satu faktor yang memegang peranan penting dalam usaha untuk memuaskan konsumen, yang pada akhirnya akan mempertahankan loyalitas pelanggan yang sudah dimiliki.

3. Pelayanan Pemeliharaan dan Perbaikan

Pelayanan dan pemeliharaan dan perbaikan diperlukan apabila suatu produk memiliki masa konsumsi yang lama dan memerlukan perawatan yang teratur agar dapat selalu berfungsi dengan baik, dan juga untuk melakukan perbaikan atas kerusakan yang terjadi pada produk tersebut selama pemakaiannya.

4. Fasilitas dan Perlengkapan

Fasilitas dan perlengkapan suatu produk merupakan sarana untuk melakukan layanan purna jual. Peralatan dan perlengkapan yang canggih akan dapat menentukan kelancaran pelayanan petugas dalam melakukan pemeliharaan dan perbaikan produk yang dibeli konsumen.

Citra Merek adalah sekumpulan assosiasi merek yang terbentuk dan melekat dalam benak konsumen terhadap suatu merek (Rangkuti, 2004). Pengertian brand image menurut Kotler (2000) adalah pada mulanya konsumen mengembangkan sekumpulan keyakinan merek tentang dimana posisi setiap merek dalam masing-masing atribut. Kumpulan dari keyakinan atas suatu merek tersebut akan membentuk brand image (citra merek). Brand image (citra merek) merupakan sebuah rangkaian asosiasi merek yang saling berhubungan. Semakin banyak asosiasi yang saling berhubungan maka akan semakin kuat brand image yang dimiliki 
oleh merek tersebut (Rangkuti, 2004). Citra merek berpengaruh secara positif terhadap pembentukan loyalitas (Sondoh Jr dkk, 2007).

Peter \& Olson (dalam Lutiary Eka Ratri, 2007) Citra merek didefinisikan sebagai persepsi konsumen dan preferensi terhadap merek, sebagaimana yang direfleksikan oleh berbagai macam asosiasi merek yang ada dalam ingatan konsumen. Meskipun asosiasi merek dapat terjadi dalam berbagai macam bentuk tapi dapat dibedakan menjadi asosiasi performansi dan asosiasi imajeri yang berhubungan dengan atribut dan kelebihan merek.

Citra merek (Brand Image) merupakan representasi dari keseluruhan persepsi terhadap merek dan dibentuk dari informasi dan pengalaman masa lalu terhadap merek itu. Citra terhadap merek berhubungan dengan sikap yang berupa keyakinan dan preferensi terhadap suatu merek. Konsumen yang memiliki citra yang positif terhadap suatu merek, akan lebih memungkinkan untuk melakukan pembelian Keller (1993) menyatakan bahwa citra merek adalah persepsi tentang merek yang digambarkan oleh asosiasi merek yang ada dalam ingatan konsumen. Ferinda Dewi (2009) berpendapat citra merek adalah merupakan konsep yang diciptakan oleh konsumen karena alasan subjektif dan emosi pribadinya.

Dari beberapa pendapat para ahli di atas dapat disimpulkan bahwa citra merek adalah persepsi konsumen dan preferensi terhadap merek, sebagaimana yang direfleksikan oleh berbagai macam asosiasi (presepsi) merek yang ada dalam ingatan konsumen.

Fanatisme adalah sebuah bentuk dari karakteristik yang kuat, hebat, dan komitmen pada level yang ekstrim, kesetiaan, pemujaan, hasrat, kasih saying, antusiasme dan keterlibatan (Bristow dan Sebastian, 2001; Cova, 2002; Funk Jams, 2001, dalam Chung, 2008). Selanjutnya Atkin(2004) mendefinisikan cult band sebagai sebuah merek yang kepada mereka sekelompok pelanggan menunjukkan kesetiaan atau dedikasi mereka yang amat tinggi, memiliki ideology tersendiridengan komunitas yang amat jelas dan berkomitmen, serta kesetiaan mereka yang sangat eksklusif dan para anggotanya seringkali menjadi pembelapembela yang tulus. Sedangkan Ragas dan Bueno (2002) memberikan cult brand sebagai semua merek tertentu yang memiliki keloyalan pelanggan super tinggi dan hamper semua pelanggannya evangelical customers atau evangelical followers yang setia kepada merek, Ragas dan Bueno juga menjelaskan proses cult branding sebagai mengubah perusahaan, orang, tempat atau organisasi menjadi suatu entitas dengan pengikut yang devoited (berbakti) dan fanatik.

Sebuah merek yang dapat memunculkan asosiasi yang kuat dalam benak konsumen, pengalaman positif ketika memakai, dan menjadikan konsumen memiliki loyalitas tertinggi serta memiliki ikatan yang kuat dengan merek tersebut dalam jangka waktu lama dapat dikategorikan sebagai cult brand (merek yang dipuja). Ketika merek telah mencapai level ini, perusahaan akan mendapatkan kemewahan yang tidak akan didapat pesaing berupa customer involvement yang sangat tinggi dan loyalitas yang tidak mungkin tertandingi oleh para pesaing (Kartajaya, 2002). Merek memiliki kapasitas untuk membangkitkan fanatisme seperti kultus (Atkin, 2004).

Loyalitas konsumen terhadap sebuah merek berbeda -beda. Terdapat salah satu jenis loyalitas yakni consumer fanaticism atau loyalitas fanatik, yang di tandai oleh komitmen, kesetiaan, devosi atau pengabdian, passion, ikatan emosional, antusiasme, dan keterlibatan (Chung \& Farrelly, 2005). Konsumen fanatic menunjukkan " extreme devotion to a brand " dimana merek menjadi bagian penting yang berpengaruh dalam kehidupan konsumen(Chung \& Farrelly, 2005). Apapun akan dilakukan untuk tetap menggunakan dan menjaga merek tersebut, dimana hal ini konsumen telah mencapai pemujaan terhadap suatu merek (cult brand).

Menurut Kotler, 1994 (dalam Tjptono 2006) .Kepuasan pelanggan adalah tingkat perasaan seseorang setelah membandingkan kinerja (hasil) yang ia rasakan dibandingkan dengan harapannya. Sedangkan menurut Tjiptono (2006) Kepuasan atau ketidakpuasan 
pelanggan terhadap evaluasi ketidaksesuaian atau diskonfirmasi yang dirasakan antara harapan sebelumnya (atau norma kinerja lainnya) dan kinerja produk yang dirasakan setelah pemakainnya. Kemudian menurut Kotler (2004), menyatakan kunci dalam mempertahankan pelanggan adalah kepuasan pelanggan. Pelanggan yang merasa puas akan memberikan keuntungan terhadap perusahaan, seperti:

1. Membeli lebih banyak dan setia lebih lama

2. Membeli jenis produk baru atau produk yang disempurnakan dari perusahaan

3. Mengumpulkan pujian bagi perusahaan dan produknya kepada orang lain

4. Kurang memperhatikan merek dan iklan pesaing, serta kurang sensitif terhadap harga

5. Memberikan gagasan baru atas barang atau jasa perusahaan

Penelitian terdahulu yang digunakan sebagai bahan referensi, yang berhubungan dengan variabel penelitian ini adalah :

1. Gultom, (2014) judul penelitian : Pengaruh Merek, Saluran Distribusi Terhadap Kepuasan Pelanggan, daLoyalitas Pembelian Produk Aqua. Hasil penelitian penelitian menunjukkan bahwa merek berpengaruh signifikan terhadap kepuasan pelanggan. saluran distribusi berpengaruh signifikan terhadap kepuasan pelanggan, dan kepuasan pelanggan berpengaruh signifikan terhadap loyalitas, selanjutnya dari pengaruh total diketahui pengaruh tidak langsung variabel merek dan saluran distribusi berpengaruh lebih besar terhadap loyalitas dibandingkan pengaruh secara langsung dari masing-masing variabel.

2. Sondoh dkk (2007) meneliti tentang, The Effect of Brand Image on Overall Satisfaction and Loyalty Intention in the Context of Color Cosmetic. Hasil penelitian ini menunjukkan bahwa, adanya pengaruh yang positif antara brand image benefit terhadap loyalty intention. kemudian dimensi brand image benefit : appearance enhances dan functional mempunyai pengaruh yang positif terhadap loyalty intention sedangkan symbolic, experiential dan social benefits mempunyai pengaruh yang negatif terhadap loyalty intention. Berdasarkan penelitian diatas dapat disimpulkan bahwa Citra Merek berpengaruh secara positif dan signifikan terhadap loyalitas.

3. Primardiani Indirasari (2013), Judul penelitian : Analisis Tingkat Fanatisme Pada Merek Apple di Kalangan Mahasiswa Fisip UI. Dalam cult brand terdapat tujuh dimensi yang digunakan dalam mengukur tingkta fanatisme merek apple yaitu, be different, determination, lifestyle, evangelist, communities, inclusive, freedom. Dari ketujuh dimensi tersebut menunjukkan dinilai responden positif, sehingga dapat di katakan bahwa fanatisme merek Apple di kalangan mahasiswa Fisip UI cukup tinggi. Hasil penelitian menunjukkan tingkat fanatisme merek Apple pada mahasiswa Fisip UI cukup tinggi, hal ini terlihat melalui penilaian mean pada 26 dari 30 indikator dalam variable cult brand yang berada pada kategori tinggi. Sedangkan sisanya adalah satu indikindicator kategori sangat tinggi dan 3 indikator pada kategori cukup.

Berdasarkan landasan teori dan penelitian terdahulu di atas, maka dapat disusun kerangka konseptual penelitian seperti ditunjukkan pada Gambar 1. Berdasarkan kerangka konseptual tersebut, maka dapat disusun hipotesis penelitian sebagai berikut :

1. Variabel Distribusi, Layanan Purna Jual, Citra Merek, dan Fanatisme Merek berpengaruh signifikan secara simultan terhadap Kepuasan Pelanggan.

2. Variabel Distribusi, Layanan Purna Jual, Citra Merek, Fanatisme Merek, dan Kepuasan Pelanggan berpengaruh signifikan secara simultan terhadap Loyalitas Pelanggan.

3. Variabel Distribusi, berpengaruh signifikan terhadap Kepuasan Pelanggan

4. Variabel Layanan Purna Jual berpengaruh signifikan terhadap Kepuasan Pelanggan.

5. Variabel Citra Merek, berpengaruh signifikan terhadap Kepuasan Pelanggan.

6. Variabel Fanatisme Merek, berpengaruh signifikan terhadap Kepuasan Pelanggan. 
7. Variabel Distribusi, berpengaruh signifikan terhadap Loyalitas Pelanggan.

8. Variabel Layanan Purna Jual, berpengaruh signifikan terhadap Loyalitas Pelanggan.

9. Variabel Citra Merek, berpengaruh signifikan terhadap Loyalitas Pelanggan.

10. Variabel Fanatisme Merek, berpengaruh signifikan terhadap Loyalitas Pelanggan.

11. Variabel Kepuasan Pelanggan, berpengaruh signifikan terhadap loyalitas Pelanggan.

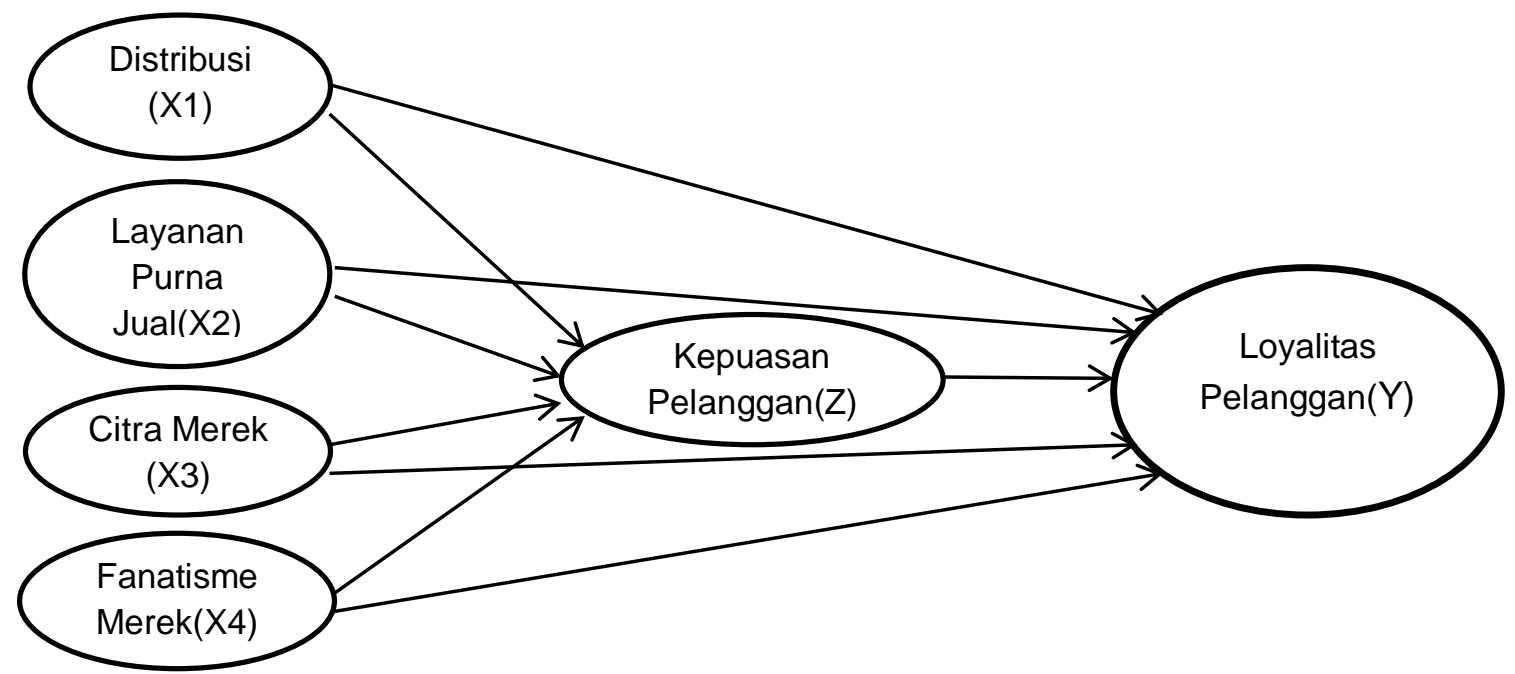

Gambar 2. Gambar Kerangka Konseptual

\section{Metode Penelitian}

Penelitian ini merupakan penelitian yang menggunakan data primer dengan metode survei. Penelitian survei adalah penelitian yang pengambilan data langsung ke lapangan yang dilakukan pada populasi yang besar maupun kecil, tetapi data yang diambil adalah data sampel dari populasi yang dianggap memenuhi syarat untuk dijadikan sampel. Instrumen penelitian yang digunakan adalah pengumpulan data primer dengan cara menyebarkan kuesioner kepada para responden. Penelitian dilakukan di Banjarmasin terhadap masyarakat pengguna/pemilik mobil merek Toyota.

Populasi dalam penelitian ini adalah seluruh masyarakat yang memiliki dan menggunakan mobil Toyota, dimana jumlah populasi tidak bisa diketahui secara pasti karena setiap saat bisa terjadi transaksi pembelian mobil Toyota yang menyebabkan populasi selalu bertambah. Dari populasi tersebut dipilih sampel. Ukuran sampel (sample size) ditetapkan berdasarkan 10 x jumlah variabel (Roscoe, dalam Sugiyono,2008). Jadi jumlah sampel minimal yang dalam penelitian ini adalah sebanyak $10 \times 6=60$ responden. Adapun jumlah sampel dalam penelitian ini adalah 100 responden, sehingga telah memenuhi syarat minimal sampel. Teknik pengambilan sampel yang dilakukan peneliti adalah accidental sampling, yaitu teknik penentuan sampel berdasarkan kebetulan, yaitu siapa saja yang secara kebetulan/incidental bertemu dengan peneliti dapat di gunakan sebagai sampel, bila dipandang orang yang kebetulan ditemui cocok sebagai sumber data(Sugiono, 2008). Sampel dalam penelitian ini adalah pemilik mobil Toyota yang ditemui di lapangan yang memenuhi syarat sebagai responden.

Variabel dalam penelitian ini terdiri dari variabel dependen dan variabel independen diuraikan sebagai berikut:

1. Variabel Dependen

Variabel dependen adalah variabel yang menjadi pusat perhatian peneliti (Ferdinand, 2006). Variabel dependen yaitu variabel yang nilainya dipengaruhi oleh variabel 
independen. Yang dijadikan sebagai variabel dependen dalam penelitian ini adalah Loyalitas.

2. Variabel Independen

Variabel independen adalah variabel yang mempengaruhi variabel dependen, baik yang pengaruhnya positif maupun yang pengaruhnya negatif (Ferdinand, 2006). Variabel independen dalam penelitian ini terdiri dari:
a. Distribusi (X1)
b. Layanan Purna Jual (X2)
c. Citra Merek (X3)
d. Fanatisme Merek (X4)

3. Variabel Intervening

Variabel Intervening adalah variabel yang mempengaruhi hubungan variabel independen dengan variabel dependen menjadi hubungan yang tidak langsung. Variabel intervenig dalam penelitian ini adalah Kepuasan Pelanggan.

\section{Hasil Penelitian dan Pembahasan}

Langkah awal yang dilakukan adalah uji validitas dan reliabilitas. Uji Validitas dan Reliabilitas instrumen penelitian dilakukan menggunakan program SPSS for windows release 16.0. Hasil analisis uji Validitas dan uji Reliabilitas disajikan pada Tabel 2.

Tabel 2. Hasil Uji Validitas

\begin{tabular}{|c|c|c|c|}
\hline \multirow[t]{2}{*}{ Variabel } & \multirow[t]{2}{*}{ Item } & \multicolumn{2}{|c|}{ Uji Validitas } \\
\hline & & Nilai $r$ hasil & Ket \\
\hline $\mathrm{X} 1$ & $\mathrm{X} 1.1$ & 0,733 & Valid \\
\hline \multirow[t]{5}{*}{ Distribusi } & $\mathrm{X} 1.2$ & 0,820 & Valid \\
\hline & $\mathrm{X} 1.3$ & 0,736 & Valid \\
\hline & $\mathrm{X} 1.4$ & 0,734 & Valid \\
\hline & $\mathrm{X} 1.5$ & 0,768 & Valid \\
\hline & $\mathrm{X} 1.6$ & 0,529 & Valid \\
\hline $\mathrm{X} 2$ & $\mathrm{X} 2.1$ & 0,629 & Valid \\
\hline Layanan & $\mathrm{X} 2.2$ & 0,754 & Valid \\
\hline \multirow[t]{2}{*}{ Purna Jual } & $\mathrm{X} 2.3$ & 0,792 & Valid \\
\hline & $\mathrm{X} 2.4$ & 0,753 & Valid \\
\hline X3 & X3.1 & 0,737 & Valid \\
\hline \multirow[t]{3}{*}{ Citra Merek } & X3.2 & 0,857 & Valid \\
\hline & X3.3 & 0,658 & Valid \\
\hline & X3.4 & 0,788 & Valid \\
\hline $\mathrm{X} 4$ & $\mathrm{X} 4.1$ & 0,852 & Valid \\
\hline Panatisme & $\mathrm{X} 4.2$ & 0,853 & Valid \\
\hline \multirow[t]{4}{*}{ Merek } & $\mathrm{X} 4.3$ & 0,818 & Valid \\
\hline & $\mathrm{X} 4.4$ & 0,836 & Valid \\
\hline & $\mathrm{X} 4.5$ & 0,809 & Valid \\
\hline & $\mathrm{X} 4.6$ & 0,778 & Valid \\
\hline $\mathrm{Z}$ & $\mathrm{Y} 1.1$ & 0,800 & Valid \\
\hline Kepuasan & $\mathrm{Y} 1.2$ & 0,937 & Valid \\
\hline \multirow[t]{3}{*}{ Pelanggan } & Y1.3 & 0,914 & Valid \\
\hline & Y1.4 & 0,906 & Valid \\
\hline & Y1.5 & 0,919 & \\
\hline $\mathrm{Y}$ & Y2.1 & 0,790 & Valid \\
\hline \multirow[t]{4}{*}{ Loyalitas } & $\mathrm{Y} 2.2$ & 0,827 & Valid \\
\hline & Y 2.3 & 0,809 & Valid \\
\hline & Y2.4 & 0,738 & Valid \\
\hline & $\mathrm{Y} 2.5$ & 0,484 & Valid \\
\hline
\end{tabular}


Berdasarkan tabel 2 diatas, dapat disimpulkan bahwa secara keseluruhan instrumen dari variabel penelitian adalah valid karena memiliki nilai koefesien korelasi $r>0,3$.

Tabel 3. Uji Reliabilias

\begin{tabular}{lll}
\hline \multirow{2}{*}{ Variabel } & UJi Reliabilitas & \\
\cline { 2 - 3 } & Nilai Alpha & Keterangan \\
\hline X1 : Distribusi & 0,794 & Reliabel \\
\hline X2 : Layanan Purna Jual & 0,796 & Reliabel \\
\hline X3: Citra Merek & & \\
\hline X4 : Fanatisme Merek & 0,731 & Reliabel \\
\hline Z : Kepuasan Pelanggan & 0,751 & Reliabel \\
\hline Y : Loyalitas Pelanggan & 0,938 & Reliabel \\
\hline
\end{tabular}

Berdasarkan tabel 3, hasil pengujian reliabilitas menunjukan bahwa seluruh alpha lebih besar dari 0,6 , sehingga dapat disimpulkan semua instrumen dalam penelitian ini adalah reliabel.

Langkah selanjutnya adalah memastikan model penelitian ini bebas dari masalah dengan menggunaka serangkaian uji asumsi klasik, meliputi:

1. UJi Heteroskedasitisitas

Deteksi terjadinya heteroskedastisitas dilakukan dengan melihat ada tidaknya pola tertentu pada grafik, dimana sumbu $\mathrm{X}$ dan $\mathrm{Y}$ yang telah diprediksi, dan sumbu $\mathrm{X}$ adalah residual ( $\mathrm{Y}$ prediksi - Y sesungguhnya) yang telah di studentized (Ghozali, 2006:105). Dasar analisis :

a. Jika ada pola tertentu, seperti titik-titik yang ada membentuk pola tertentu yang teratur (bergelombang, melebar kemudian menyempit), maka mengidentifikasikan telah terjadi heteroskedastisitas.

b. Jika tidak ada pola yang jelas, serta titik-titik menyebar di atas dan di bawah angka 0 pada sumbu Y, maka tidak terjadi heteroskedastisitas.

Hasil grafik scater plot terlihat bahwa penyebaran data menyebar di atas dan di bawah angka 0 dan tidak membentuk pola tertentu, yang berarti tidak terjadi heteroskedastisitas.

2. Uji Multikolinearitas

Uji multikolinearitas bertujuan untuk menguji apakah model regresi ditemukan adanya korelasi antar variabel independen. Multikolinearitas dapat dideteksi dengan nilai tolerance dan nilai Variance Inflation Factor (VIF).

Berdasarkan hasil perhitungan dapat diketahui bahwa nilai tolerance untuk Distribusi (X1) adalah sebesar 0,471 dan nilai VIF sebesar 2,123. Nilai tolerance pada Layanan Purna Jual (X2) adalah sebesar 0,472 dan nilai VIF sebesar 2,118. Nilai tolerance pada Citra Merek (X3) adalah sebesar 0,407 dan nilai VIF sebesar 2,457. Nilai tolerance pada Fanatisme Merek (X4) adalah sebesar 0,361 dan nilai VIF sebesar 2,772. Nilai tolerance Kepuasan Pelanggan adalah sebesar 0,352 dan nilai VIF sebesar 2,842. Berdasarkan hasil tersebut tidak ada nilai tolerance yang $<0,010$ dan tidak ada nilai VIF yang $>10$, maka dapat disimpulkan bahwa tidak terjadi multikoliearitas antar variabel bebas dalam model regresi tersebut. 
3. Uji Autokorelasi

Pengujian ini dilakukan untuk mengetahui apakah dalam model regresi linier ada korelasi antara kesalahan pengganggu pada periode waktu t dengan kesalahan pada periode waktu t-1. Penelitian ini, pengujian autokorelasi dilakukan dengan uji Durbin - Watson. Dimana kriteria Durbin - Watson adalah 1,5 - 2,5 atau $>1,5$ dan $<2,5$. Adapun hasil uji Durbin Watson diperoleh hasil sebesar 1,504 yang berarti tidak terdapat autokorelasi.

4. Uji Normalitas

Pengujian normalitas dalam penelitian ini dilakukan melihat penyebaran data (titik) pada sumbu diagonal dari grafik atau dengan melihat histogram dari residualnya, terlihat data menyebar disekitar garis diagonal dan mengikuti arah garis diagonal selanjutnya grafik histogram menunjukkan pola distribusi normal maka model regresi memenuhi asumsi normalitas.

Langkah selanjutnya adalah membuat analisis jalur. Analisis jalur dilakukan dengan tujuan untuk mengukur pengaruh secara tidak langsung variabel distribusi, layanan purna jual, citra merek dan fanatisme merek terhadap keputusan pelanggan dan loyalitas. Analisis jalur dalam penelitian ini dilakukan dengan uji regresi berganda dua tahap, yaitu menguji pengaruh secara langsung dan pengaruh tidak langsung, dengan menggunakan program SPSS for window release 22, seperti terlihat pada tabel 4 .

Tabel 4. Hasil Uji Regresi Berganda pengaruh variabel distribusi, layanan purna jual, fanatisme merek terhadap kepuasan pelanggan

\begin{tabular}{|c|c|c|c|c|}
\hline \multicolumn{5}{|c|}{ Model Summary } \\
\hline Model & $\mathrm{R}$ & $\begin{array}{c}\mathrm{R} \\
\text { Square }\end{array}$ & Adjusted R Square & Std. Error of the Estimate \\
\hline 1 &, $805^{\mathrm{a}}$ & ,648 & ,632 & 1,4131 \\
\hline
\end{tabular}

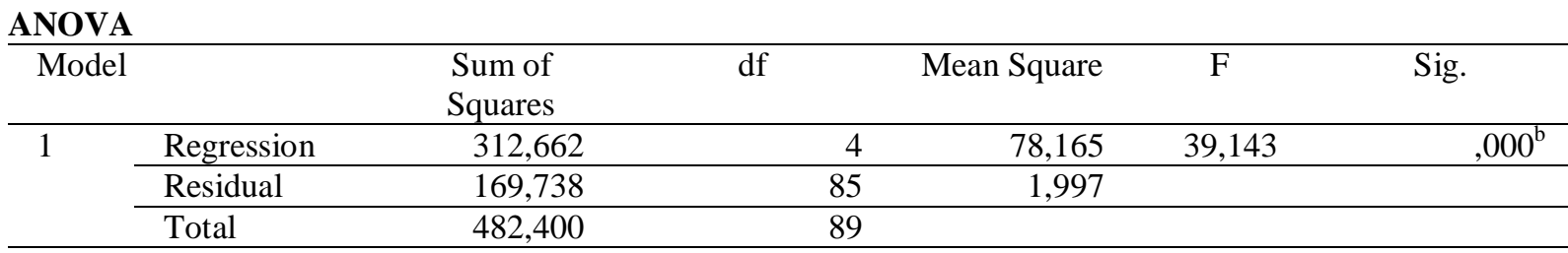

a. Dependent Variable: KEP PELANGGAN

b. Predictors: (Constant), FANATISME MEREK, LAY PURNA JUAL, Dustribusi, CITRA MEREK

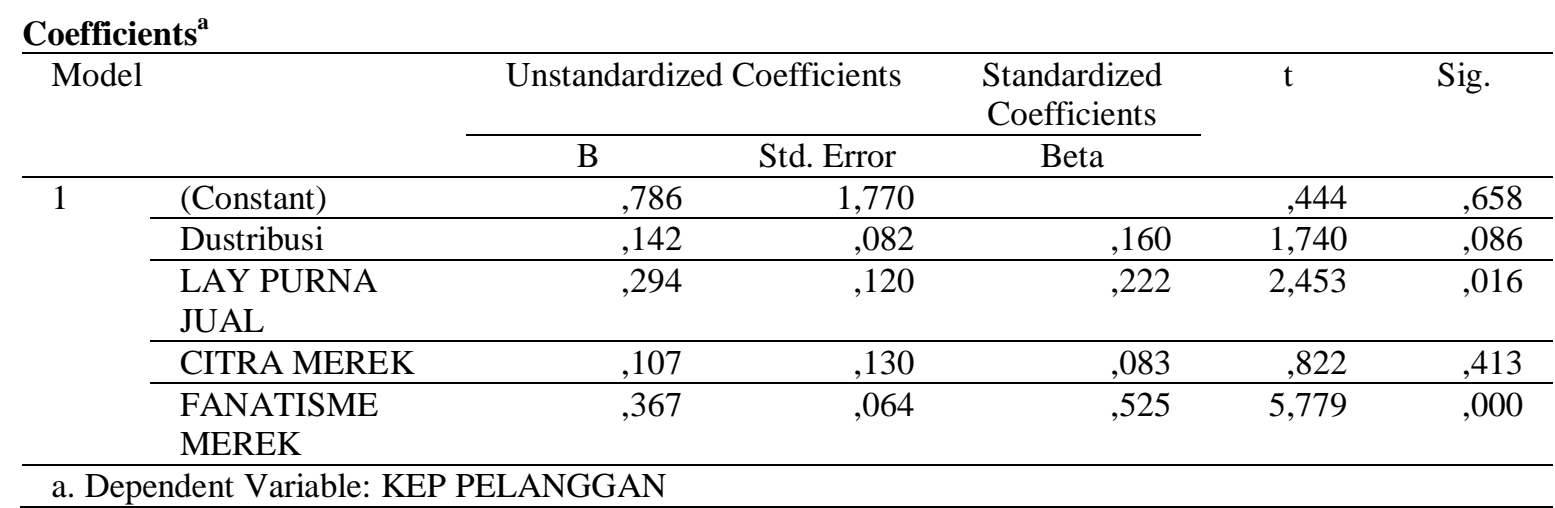


Tabel 5. Hasil Uji Regresi Berganda Pengaruh Variabel Distribusi, Layanan Purna Jual, Fanatisme Merek Terhadap Loyalitas

\begin{tabular}{lccccc}
\multicolumn{2}{l}{ Model Summary } & & & \\
\hline Model & $\mathrm{R}$ & $\mathrm{R}$ & Std. Error of the Estimate & \\
Square & $\begin{array}{c}\text { Adjusted R } \\
\text { Square }\end{array}$ & & 1,9163 \\
\hline 1 &, $840^{\mathrm{a}}$ &, 705 &, 687 & & \\
\hline $\begin{array}{l}\text { a. Predictors: (Constant), KEP PELANGGAN, LAY PURNA JUAL, CITRA MEREK, Distribusi, } \\
\text { FANATISME MEREK }\end{array}$ & & & \\
\hline
\end{tabular}

\begin{tabular}{|c|c|c|c|c|c|c|}
\hline \multicolumn{7}{|c|}{ ANOVA } \\
\hline Model & & $\begin{array}{c}\text { Sum of } \\
\text { Squares }\end{array}$ & df & Mean Square & $\mathrm{F}$ & Sig. \\
\hline \multirow[t]{3}{*}{1} & Regression & 736,519 & 5 & 147,304 & 40,113 &, $000^{\mathrm{b}}$ \\
\hline & Residual & 308,469 & 84 & 3,672 & & \\
\hline & Total & 1044,989 & 89 & & & \\
\hline \multicolumn{7}{|c|}{ a. Dependent Variable: LOYALITAS } \\
\hline \multicolumn{7}{|c|}{$\begin{array}{l}\text { b. Predictors: (Constant), KEP PELANGGAN, LAY PURNA JUAL, CITRA MEREK, Distribusi, } \\
\text { FANATISME MEREK }\end{array}$} \\
\hline
\end{tabular}

\section{Coefficients}

\begin{tabular}{|c|c|c|c|c|c|c|}
\hline \multirow{2}{*}{\multicolumn{2}{|c|}{ Model }} & \multicolumn{2}{|c|}{ Unstandardized Coefficients } & \multirow{2}{*}{$\begin{array}{c}\text { Standardized Coefficients } \\
\text { Beta }\end{array}$} & \multirow[t]{2}{*}{$\mathrm{t}$} & \multirow[t]{2}{*}{ Sig. } \\
\hline & & $\mathrm{B}$ & Std. Error & & & \\
\hline \multirow[t]{6}{*}{1} & (Constant) & $-3,744$ & 2,403 & & $-1,558$ &, 123 \\
\hline & Distribusi &,- 122 &, 113 &,- 094 & $-1,083$ &, 282 \\
\hline & LAY PURNA JUAL & ,364 & , 168 & 187 & 2,164 & ,033 \\
\hline & CITRA MEREK &,- 239 & 178 &,- 125 & $-1,347$ & 182 \\
\hline & FANATISME MEREK & ,744 &, 102 & ,722 & 7,314 &, 000 \\
\hline & KEP PELANGGAN & 311 & 147 & 211 & 2,111 & 038 \\
\hline
\end{tabular}

a. Dependent Variable: LOYALITAS

Berdasarkan hasil perhitungan besarnya koefesien korelasi adjusted R Square adalah sebesar 0,687. Hal ini berarti 68,7 \% variasi dari Loyalitas dapat dijelaskan oleh kelima variabel independen yaitu Distribusi, Layanan Purna Jual, Citra Merek, Fanatisme Merek dan Kepuasan Pelanggan. Sedangkan sisanya sebesar 31,3 \% dijelaskan oleh faktor - faktor lain diluar model.

Berdasarkan uji regresi tahap 1, variabel Distribusi dan Citra Merek tidak berpengaruh signifikan terhadap Kepuasan Pelanggan karena nilai signifikansi $>0,05$. Sedangkan variabel Layanan Purna Jual dan Fanatisme Merek berpengaruh signifikan terhadap Kepuasan Pelanggan karena nilai signifikansinya $<0,05$. Selanjutnya uji regresi tahap 2 , variabel Distribusi dan Citra Merek tidak berpengaruh signifikan terhadaap Loyaitas karena nilai signifikansi > 0,05. Sedangkan variabel layanan Purna Jual dan Fanatisme Merek dan Kepuasan Pelanggan berpengaruh signifikan terhadap Kepuasan Pelanggan karena nilai signifikansinya $<0,05$. berikut:

Berdasarkan dari hasil uji regresi, dapat ditulis persamaan model regresi sebagai

$\mathrm{Z}=0,786+0,142(\mathrm{X} 1)+0,294(\mathrm{X} 2)+0,107(\mathrm{X} 3)+0,367(\mathrm{X} 4)+\mathrm{e}$

$\mathrm{Y}=-3,744+0,122(\mathrm{X} 1)+0,364(\mathrm{X} 2)-0,239(3)+0,744(\mathrm{X} 4)+0,311(\mathrm{X} 5)+\mathrm{e}$

Dari uji regresi tersebut variabel yang tidak berpengaruh signifikan secara parsial tidak masuk dalam analisis jalur karena tidak membentuk pola hubungan baik langsung maupun tidak langsung terhadap variabel dependen. 
Selanjutnya untuk mengetahui pengaruh langsung dan tidak langsung variabel maka digunakan perhitungan pengaruh total sebagai berikut:

- Pengaruh total dari X2 ke Y melalui Z

- Pengaruh Langsung dari X2 ke Y

- Pengaruh Tidak langsung dari X1 ke Y melalui $Z=0,222 \times 0,211$

$=0,047$

○ Pengaruh Total

$=0,301$

- Pengaruh total dari X4 ke Y melalui Z

o Pengaruh Langsung dari X4 ke Y

$=0,722$

$\circ$ Pengaruh Tidak langsung dari X2 ke Y melalui $Z=0,525 \times 0,211=0,111$

○ Pengaruh Total

$=0,833$

Keterangan :

$\mathrm{X} 1$ = Layanan Purna Jual

$\mathrm{X} 2$ = Fanatisme Merek

$\mathrm{Z}=$ Kepuasan Pelanggan

$\mathrm{Y}=$ Loyalitas

Berdasarkan hasil perhitungan tersebut maka dapat di buat gambar analisis jalur seperti ditunjukkan pada Gambar 2.

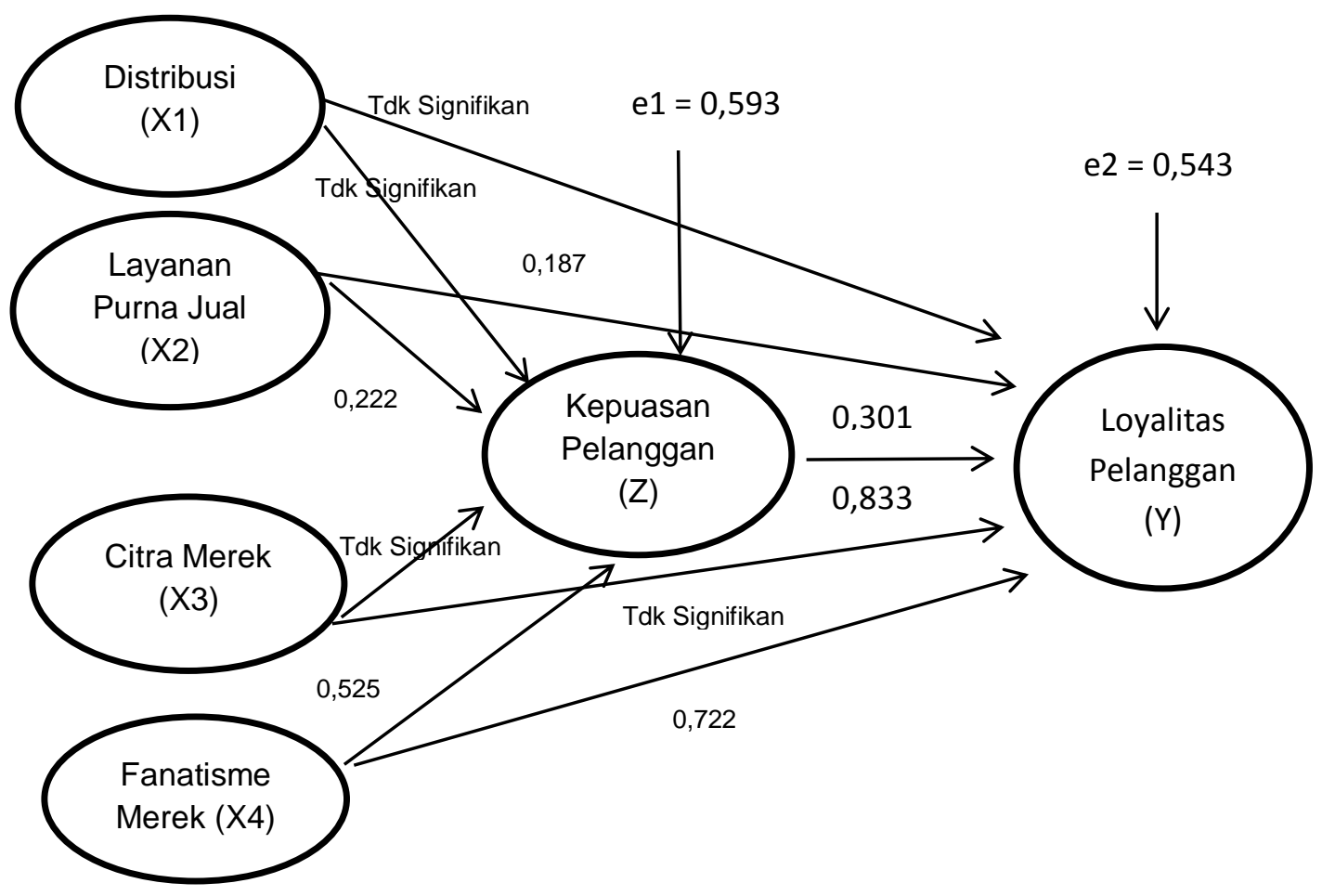

\section{Gambar 2. Kerangka Konseptual Model Analisis Jalur}

Berdasarkan pada hasil penelitian yang telah ditemukan, maka dapat dilakukan Uji Hipotesis sebagai berikut:

1. Uji Signifikansi Secara Simultan

Berdasarka uji regresi tahap 1 diperoleh hasil uji ANOVA atau F test didapat $\mathrm{F}$ hitung sebesar 39,143 dengan signifikansi 0.000. Karena signifikansi jauh lebih kecil dari 0.05, maka dapat dikatakan bahwa Distribusi, Layanan Purna Jual, Citra Merek dan Fanatisme Merek secara bersama-sama berpengaruh signifikan terhadap Kepuasan Pelanggan. Hasil 
uji regresi tahap 2 diperoleh hasil uji ANOVA atau F test didapat F hitung sebesar 40,143 dengan signifikansi 0.000. Karena signifikansi jauh lebih kecil dari 0.05, maka dapat dikatakan bahwa Distribusi, Layanan Purna Jual, Citra Merek, Fanatisme Merek dan Kepuasan Pelanggan secara bersama-sama berpengaruh signifikan terhadap Loyalitas Pelanggan.

2. Uji Signifikansi Secara parsial

Hipotesis pertama menyatakan bahwa Ditribusi berpengaruh signifikan terhadap Kepuasan Pelanggan. Hipotesis ini ditolak karena signifikansi 0,086 > 0,05. Hal ini berarti bahwa variabel Distribusi tidak berpengaruh signifikan terhadap Kepuasan Pelanggan.

Hipotesis kedua menyatakan bahwa Layanan Purna Jual berpengaruh signifikan terhadap Kepuasan Pelanggan. Hipotesis ini diterima karena signifikansi 0,016 < 0,05. Hal ini berarti bahwa variabel Layanan Purna Jual berpengaruh signifikan terhadap Kepuasan Pelanggan.

Hipotesis ketiga menyatakan bahwa Citra Merek berpengaruh signifikan terhadap Kepuasan Pelanggan. Hipotesis ini ditolak karena signifikansi 0,413>0,05. Hal ini berarti bahwa variabel citra merek tidak berpengaruh signifikan terhadap Kepuasan Pelanggan.

Hipotesis keempat menyatakan bahwa Fanatisme Merek berpengaruh signifikan terhadap Kepuasan Pelanggan. Hipotesis ini diterima karena tingkat signifikansi $0,000<0,05$. Hal ini berarti bahwa variabel Fanatisme Merek berpengaruh signifikan terhadap Kepuasan Pelanggan.

Hipotesis kelima menyatakan bahwa Ditribusi berpengaruh signifikan terhadap Loyalitas Pelanggan. Hipotesis ini ditolak karena signifikansi 0,282 >0,05. Hal ini berarti bahwa variabel Distribusi tidak berpengaruh signifikan terhadap Loyalitas Pelanggan.

Hipotesis keenam menyatakan bahwa Layanan Purna Jual berpengaruh signifikan terhadap Loyalitas Pelanggan. Hipotesis ini diterima karena signifikansi $0,033<0,05$. Hal ini berarti bahwa variabel Layanan Purna Jual berpengaruh signifikan terhadap Loyalitas Pelanggan.

Hipotesis ketujuh menyatakan bahwa Citra Merek berpengaruh signifikan terhadap Loyalitas Pelanggan. Hipotesis ini ditolak karena signifikansi $0,182>0,05$. Hal ini berarti bahwa variabel Citra Merek tidak berpengaruh signifikan terhadap Loyalitas Pelanggan.

Hipotesis kedelapan menyatakan bahwa Fanatisme Merek berpengaruh signifikan terhadap Loyalitas Pelanggan. Hipotesis ini diterima karena tingkat signifikansi $0,000<$ 0,05. Hal ini berarti bahwa variabel Fanatisme Merek berpengaruh signifikan terhadap Loyalitas Pelanggan.

Hipotesis kesembilan menyatakan bahwa Kepuasan Pelanggan berpengaruh signifikan terhadap Loyalitas Pelanggan. Hipotesis ini diterima karena signifikansi $0,038<0,05$. Hal ini berarti bahwa variabel Kepuasan Pelanggan berpengaruh signifikan terhadap Loyalitas Pelanggan.

3. Hasil Uji Dominan

Berdasarkan hasil uji secara parsial, diketahui bahwa variabel Fanatisme Merek berpengaruh paling dominan terhadap Loyalias Pelanggan karena memiliki nilai koefesien regresi terbesar yaitu 0,744 .

\section{Kesimpulan} berikut:

Berdasarkan pada hasil penelitian, maka dapat dibuat serangkaian kesimpulan sebagai

1. Variabel Distribusi, Layanan Purna Jual, Citra Merek dan Fanatisme Merek secara simultan berpengaruh signifikan terhadap Kepuasan Pelanggan. 
2. Variabel Distribusi, Layanan Purna Jual, Citra Merek, Fanatisme Merek dan Kepuasan Pelanggan berpengaruh secara simultan terhadap Loyalitas Pelanggan.

3. Variabel Distribusi Dan Citra Merek, secara parsial tidak berpengaruh signifikan terhadap Kepuasan Pelanggan. Sedangkan variabel Layanan Purna Jual dan Fanatisme Merek berpengaruh signifikan terhadap Kepuasan Pelanggan.

4. Variabel Distribusi Dan Citra Merek, secara parsial tidak berpengaruh signifikan terhadap Loyalitas Pelanggan. Sedangkan variabel Layanan Purna Jual, Fanatisme Merek dan Kepuasan Pelanggan berpengaruh signifikan terhadap Loyalitas Pelanggan. Dilihat dari pengaruh langsung dan tidak langsung maka variabel Layanan Purna Jual dan Fanatisme merek berpengaruh lebih besar secara tidak langsung terhadap Loyalitas melalui Kepuasan Pelanggan.

5. Variabel Fanatisme Merek merupakan variabel yang paling dominan mempengaruhi Loyaitas Pelanggan.

Berdasarkan pada kesimpulan diatas, maka dapat diajukan beberapa saran sebagai berikut:

1. Perusahaan Toyota harus terus menjaga dan mempertahankan fanatisme masyarakat terhadap mobil toyota, terbukti variabel ini berpengaruh paling dominan terhadap loyalitas pelanggan, yang berarti selama ini masyarakat memilih mobil Toyota karena perasaan fanatik mereka. Hal ini mungkin disebabkan karena merek Toyota sudah sangat kuat melekat dihati masyarakat dan sudah menjadi kebiasaan masyarakat menggunakan mobil Toyota. Pengaruh tidak langsung fanatisme merek berpengaruh lebih kuat terhadap loyalitas yang berarti semakin tinggi kepuasan pelanggan maka semakin tinggi loyalitas pelanggan, maka kebijakan yang harus dilakukan perusahaan adalah selalu menciptakan mobil yang berkualitas dengan harga kompetitif dan selalu berinovasi mendahului pesaing sesuai slogan Toyota "moving forward" dengan tujuan meningkatkan kepuasan pelanggan. Kemudian variabel layanan purna jual berpengaruh signifikan terhadap loyalitas, dimana pengaruh secara tidak langsung terhadap loyalitas lebih tinggi apabila melalui kepuasan pelanggan, hal ini berarti layanan purna jual harus terus ditingkatkan sehingga dapat meningkatkan kepuasan kepada pelanggan dengan cara memperbaiki terus-menerus pelayanan bengkel resmi Toyota dengan menyediakan peralatan dan fasilitas lengkap untuk kenyamanan servis, meningkatkan kemampuan para mekanik melalui pelatihan yang kontinyu dan ketersedian suku cadang.

2. Variabel Distribusi dan Citra Merek tidak berpengaruh signifikan terhadap keputusan pembelian mobil Toyota, hal ini berarti faktor tersebut kurang diperhatikan atau tidak dipertimbangkan oleh masyarakat ketika membeli mobil Toyota. Namun hal tersebut tidak lalu menjadikan perusahaan tidak memperhatikan faktor tersebut, bisa saja masyarakat tidak mempertimbangkan variabel tersebut karena telah menganggap variabel tersebut sudah sangat baik, yang berarti variabel distribusi, dan citra merek Toyota selama ini telah dianggap baik dan sesuai dengan exspektasi masyarakat, sehingga hal tersebut merupakan suatu keunggulan Toyota dibanding merek mobil yang lain. Oleh karena itu variabel variabel tersebut harus terus jadi perhatian perusahaan dan terus menerus melakukan perbaikan.

3. Bagi peneliti berikutnya yang menganggangkat masalah yang sama hendaknya mempertimbangkan variabel lainya di luar model ini, dan memperbanyak sampel penelitian, mengingat mobil Toyota memiliki pengguna yang sangat banyak. 


\section{DAFTAR PUSTAKA}

Aaker, David. A. 1996, Building Strong Brands. New York: The Free Press.

Atkin, Douglas, 2004. The Culting Of Brand : When Customer Become True Believers, Now York : Portofolio.

Chung, dkk, 2005. Exploring Consumer fanaticism \& Fresh Perspective on The Concept of Loyalty. ANZMAC 2005 Conference Consumer behaviour.

Chung, dkk,2008. Exploring Consumer Fanaticism: Extraordinary Devotion in the Consumption Context, Jurnal Advances in Consumer Research (Volume 35) / 335.

Ghozali, Imam, 2005, Aplikasi Multivariate Dengan Program SPSS, Badan Penerbit Diponegoro.

Gultom, 2014. Pengaruh Merek, Saluran Distribusi Terhadap Kepuasan Pelanggan, Loyalitas Pembelian Produk Aqua.

Herman, 2016. Toyota Kuasai Hampir Seluruh Segmen Mobil di Indonesia http://www.beritasatu.com/mobil/385848-toyota-kuasai-hampir-seluruh-segmen-mobildi-indonesia.html, diakses tanggal 25 jan 2017

Indirasari, Primardiani, 2013. Analisis Tingkat Fanatisme Pada Merek Apple di Kalangan Mahasiswa Fisip UI.

Kartajaya, Hermawan, 2002. Hermawan Kartajaya On Marketing. Jakarta : PT Gramedia Pustaka Utama.

Keller. (1993). How to manage brand equty. Jakarta: gramedia pustaka.

Kotler, Philip, dan Amstrong, Gary, 2001, Dasar-dasar Pemasaran, Jilid Satu, Edisi Kesembilan, Penerbit PT. Gramedia Pustaka Utama : Jakarta

Kotler, Philip dan Keller, Kevin Lane, 2008, Manajemen Pemasaran. Edisi Kedua Belas Jilid 1, Penerbit PT. Indeks, Jakarta

Kotler, Philip; Armstrong, Garry, 2008. Prinsip -prinsip Pemasaran, Jilid 1, Erlangga, Jakarta.

Simamora, 2005. Penerapan Prinsip-Prinsip Pemasaran, Jakarta, PT Bumi Aksara.

Sondoh, dkk, 2007, The Effect of Brand Image on Overall Satisfaction and Loyalty Intention in the Context of Color Cosmetic. Asian Academy of Management Journal, Vol. 12, No. 1, 83-107, Januari 2007.

Tjiptono, Fandy, 2008, Strategi Pemasaran, Edisi 3, ANDI: Yogyakarta.

Sugiyono, 2008, Metode Penelitian Bisnis, Cetakan Keduabelas, Penerbit Alfabeta Bandung. 